\title{
Is It Time To Give Up the Fight Against Inflation?
}

\author{
Address by LAWRENCE K. ROOS, President, Federal Reserve Bank of St. Louis, before the Petroleum \\ and Chemical Industry Conference of the Institute of Electrical and Electronic Engineers, St. Louis, \\ Missouri, August 30, 1982
}

I

AM pleased to have this opportunity to appear before you at at time when critical decisions concerning the future course of economic policy are being made.

For almost 15 years, from the mid-60s to 1980 , Americans endured accelerating inflation. During that period when prices rose from an annual rate of less than two percent to double-digit dimensions, our economy became afflicted by problems which increasingly weakened the industrial and commercial sinews of this nation. By the end of the 1970 s, it became apparent that we were losing the war against inflation. Our losses consisted of more than just higher prices; we suffered signficant declines in productivity, sizable reductions in investment and savings growth, rapidly rising interest rates, volatile financial markets, increasing unemployment and a host of other social problems.

Toward the end of 1979, the Federal Reserve took decisive steps to halt the rising growth in money that had spawned the inflation. Its goal became disinflation - a gradual reduction in the rate of inflation through a gradual reduction in the growth of the money supply.

Today, after nearly three years of the new policy, we seem to be on the threshold of success. For the first time in several years, inflation has dropped substantially. So far this year, on an annual basis, prices have risen only about 5 percent, a significant improvement over the double-digit figures of a few years ago.

Unfortunately, however, at the very moment of meaningful progress, we are being besieged by a varie- ty of economic ills that are severely testing our resolve to continue the fight. Among these are: increased unemployment, high interest rates, sharply reduced housing and construction activity, falling commodity prices, low rates of saving and investment, and what some observers see as a declining competitive advantage for our products in foreign markets.

It is becoming increasingly popular in some circles to attribute our current economic ills to our disinflation efforts. Almost daily we are inundated by articles with titles like "How Disinflation Hurts Us All," "The Costs of Disinflation," or, even more alarming, "The Curse of Disinflation." Congressmen have been quoted as equating our current anti-inflation efforts to the PLO's efforts in West Beirut, hinting that, if continued, our disinflation policies will reduce the nation's economy to a pile of rubble. When the Chairman of the Federal Reserve System recently appeared before Congress, he was urged to "consider a major change in monetary policy before it is too late." Bills have been introduced in Congress to force the Federal Reserve to abandon its efforts to reduce monetary growth and to revert to interest rate targeting - the very same procedure that produced our past inflation.

In the face of this sort of prodding, it is not surprising that more and more people are asking whether the time has indeed come for us to move away from disinflation and reinflate our way back to more "prosperous" times. It is this issue that I would like to discuss with you. 
Now, I am not going to tell you that disinflation is without its costs. It is not costless. To bring down and hold down inflation after 15 years of soaring prices requires a major overhanling of our economic system. And, as in any major overhaul, there will be a certain amount of "downtime" - a temporary reduction in output and a rise in unemployment - as we retool for a different economic environment. However, I want to stress that this downtime, for most sectors of the economy, is only temporary. It marks a necessary transition to a stable economic environment essential for longer term growth and prosperity.

Also, it is important to recognize that not all industries will do well even if inflation is halted. Some will suffer permanent losses - especially those that, for a variety of reasons, benefit from inflation. Among these are speculative land and commodity firms, companies that produce and sell "collectibles" of all kinds, and, perhaps, even those publishing companies that market books on "how to beat inflation."

Reform is never without its costs, but in considering whether the time has really arrived to reinflate, I would like to pose two questions: First, is disinflation solely responsible for our current economic problems? Second, can we solve our problems by returning to our old "inflation as usual" policies? I will argue that the answer to both of these questions is "No."

First, let's consider why disinflation, per se, is not the sole cause of our current economic problems. Certainly disinflation is responsible for some temporary problems. However, some of our most serions problems would have occurred even if inflation had continued; they are the direct result of a new awareness on the part of the public of the pernicious nature of inflation and people's actions to attempt to protect themselves from some of its effects.

In the early 1970 s, when serious inflation was a new experience for most Americans, people tended to view rising prices as a temporary phenomenon that, like an old soldier, would somehow fade away. While no one in retrospect would question that the decade of the 1970 s was one of rising inflation, many people at that time behaved as if inflation either didn't exist or, at least, wouldn't persist. Being unconditioned to inflation, they totally failed to anticipate either the extent or the duration of the problem. As a result many people - perhaps you and I included - continued to save and lend money at interest rates that failed to compensate for our loss of future purchasing power that came about as a result of inflation. This was true even for many sophisticated financiers whose activities influence interest rates.

As a result, the real interest rate that savers and lenders received - the actual return after adjusting for the impact of inflation - was not only ridiculously low during the inflationary $70 \mathrm{~s}$, it was negative for much of the decade. Now, whenever the real rate of return on financial assets - such as bonds, savings accounts and the like - is unrealistically low - or even worse, when it is negative - people who hold financial assets - the savers - end up poorer and people who sell financial assets to them - the borrowers - end up wealthier. During the $1970 \mathrm{~s}$, people who borrowed funds to purchase tangible assets - houses, cars, land, gold, etc. - did well; those who lent funds did badly. Of course, nobody plamed it that way. It was, however, a predictable result of the public's failure to recognize the true nature and extent of inflation.

To illustrate how this works, let's take a simple example. Consider two individuals, each of whom expects the rate of inflation to average 5 percent per year over the next ten years. Let's further assume that the competitive real rate of interest at that time (i.e., the actual return above the rate of inflation) is 3 percent per year. If one borrows $\$ 100,000$ from the other to purchase a house, the borrower would be willing to pay (and the lender would expect to receive) an 8 percent interest rate on the loan -5 percent to compensate for expected inflation and 3 percent to provide a desired real return.

Suppose, however, that the actual rate of inflation over the ten year period turned out to be 9 percent per year, instead of the 5 percent that was originally expected and factored into the loan. If this happened, the lender would be the loser. He would be receiving 8 percent each year on an investment that was eroding in value, due to inflation, at 9 percent per year. Instead of a positive real rate of return of 3 percent, he would be losing one percent in terms of his annual real rate of return.

On the other hand, the borrower would be doing unexpectedly well. He would be paying 8 percent ammual interest on a house that was appreciating in value at 9 percent per year - and getting a real return from living in it as well. In times of unexpected inflation, the lender's loss is the borrower's gain. And many people failed to compensate for this factor during the inflationary 1970s.

However, as this disparity between individual rates of return on real versus financial assets became in- 
creasingly noticeable over time, people became attuned to the meaning of inflation and took steps to protect themselves against it. They did this by purchasing tangible assets such as houses, land, commodities of all kinds - and by refraining from purchasing financial assets that were depreciating in value.

It was simply a situation of people awakening to what was happening and adjusting their investments to compensate for some of the effects of inflation. As a consequence, land values increased dramatically. Housing prices, on average, rose 2.5 percent per year faster than the rate of inflation. Inventories became one of the best ways to hold corporate wealth. Commodity prices soared - the price of gold alone rose nearly 21 percent per year above the rate of inflation. Even if OPEC had not existed, petroleum products would have been a boom industry. On the other hand, financial markets foundered. Investors in bonds and money market instruments earned negative real rates of return ranging from -0.2 to -0.5 percent per year.

The consequences were inevitable: savers got poorer and the supply of credit declined; borrowers got wealthier and the demand for credit rose. As a result, real interest rates began to rise. Moreover, the public got smarter; after 15 years of living with inflation, people finally came to realize the extent and persistence of the problem and adjusted their economic decisions so as to reduce, as much as possible, the dislocations that inflation produces. Both savers and lenders learned to insist on a return that would preserve their purchasing power as well as compensate them for the greater risk of lending during a period of uncertain inflation. And all of this, of course, put even further upward pressure on real interest rates.

By the beginning of the $1980 \mathrm{~s}$, inflation awareness, not inflation naivete, dictated the direction of financial dealings. Real interest rates became positive and the benefits people had previously enjoyed from borrowing to acquire real assets evaporated. As a result, certain sectors of the economy such as housing, land speculation, commodity purchases, etc., that had previously been subsidized by invalid and erroneous inflationary anticipations began to experience a decline. Similarly, gold prices fell, while bonds and money market instruments finally began yielding positive real rates of return.

What happened, in a nutshell, was that the public learned to recognize and anticipate the effects of changes in the rate of inflation and, as a result, is now better prepared to adjust its economic decisions accordingly. It is that adjustment process, and not the process of disinflation itself, that accounts for current relatively high interest rates and most of the dislocations that have occurred in the economy. And it is that adjustment process that has important implications for assessing whether reinflation would provide any relief from our current problems.

The issue, therefore, is what will we gain if we abandon our disinflation efforts? Can we remflate our way back to more prosperous times?

To some extent, advocates of reinflation are simply victims of misplaced nostalgia or selective amnesia. Critios of today's disinflation policies seem to have forgotten that the 1970s were not good years for this nation. During the inflationary 1970 s real economic growth fell about 25 percent below what it had been during the $1960 \mathrm{~s}$; the unemployment rate, which had averaged less than 4 percent in the last half of the $60 \mathrm{~s}$, averaged 7 percent from 1975 to 1979 . Long-term interest rates, which had averaged less than six percent during the late $60 \mathrm{~s}$, reached double-digit levels by the end of the 1970 s. It was precisely these problems that led us to embark on the struggle against inflation. It is precisely these long-run consequences of higher inflation that we can expect to return to if we do opt to reinflate.

Of course, there are some who feel that a return to reinflation is necessary to bring relief to certain industries that have severely suffered during the disinflation effort, such as the housing and construction industries. That reinflation would accomplish this is wishful thinking! As I've explained, the gains that inflation produced for housing and similarly affected sectors during the 1970 s arose from the fact that interest rates did not correctly reflect the full impact of inflation.

Today, however, the public has developed an inflation awareness that would prevent this from happening again. The public is now fully aware that it can protect the value of its assets only by anticipating changes in the future rate of inflation. Consequently, if the public were to believe that reinflation was imminent, interest rates would increase to protect investors' real return. Any anticipated reinflationary gains to the housing industry, or to any other interest-sensitive sectors of the economy, would be doomed by upward adjustments in interest rates resulting from heightened inflationary expectations.

This is why I find the current damor for reinflation so disturbing. It is not just that there is no evidence that excessive monetary expansion would bring the results its advocates seek; it is rather that pressure for 
reinflation raises doubts in people s minds as to whether inflation will continue to decline. In view of the rising sentiment for reinflation, it is not surprising that people remain skeptical as to the extent of our current commitment to disinflation. Many of the savers and lenders who were so badly bumed in the 1970 s understandably are sensitive to what they read and hear that implies a potential weakening of our resolve to continue the struggle against inflation.

Just recently, the American Bankers Association released a long-range inflation forecast predicting an average inflation rate of more than 9 percent per year over the next ten years. The latest Harris poll of business executives shows that many of those polled expect inflation to begin rising within one year. If bankers and business executives aren't convinced that disinflation will continue, we can hardly expect to convince lenders and savers that this will happen.
The solution to this problem, and the challenge facing us for the future, is to make our anti-inflation policies credible to a disbelieving public. There are several things that would contribute mightily to this effort. First, our current monetary policy stance must be maintained; there must be no, even temporary, reinffation "relapse," Second, federal deficits must be reduced significantly. I say this not because I believe that deficits by themselves cause inflation - they do not. I say it because smaller federal deficits would reduce the "temptation" facing monetary authorities to monetize a portion of the deficit. Finally, the American public must be prepared to resist pressures for policymakers to revert to reinflation in order to alleviate the temporary pain of the process of disinflation. Only when people become convinced that our anti-inflation fight is "for real" and will be pursued over a long period of time, will inflation finally be eliminated and stability, so necessary for economic growth, be restored.

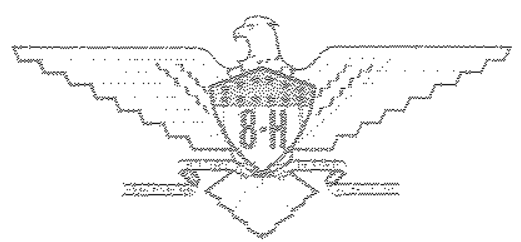

